\title{
Eucalyptus Rust: A Disease with the Potential for Serious International Implications
}

T. A. Coutinho, Department of Microbiology and Plant Pathology and Tree Pathology Co-operative Programme, and M. J. Wingfield, Tree Pathology Co-operative Programme, Forestry and Agricultural Biotechnology Institute, University of Pretoria, Pretoria 0002, South Africa; A. C. Alfenas, Department of Plant Pathology, Universidade Federal de Viçosa, Viçosa MG 36570, Brazil; and P. W. Crous, Department of Plant Pathology, University of Stellenbosch, Private Bag X1, Matieland 7602, South Africa

\begin{abstract}
Coutinho, T. A., Wingfield, M. J., Alfenas, A. C., and Crous, P. W. 1998. Eucalyptus rust: A disease with the potential for serious international implications. Plant Dis. 82:819-825.

Eucalyptus spp. are propagated extensively as non-natives in plantations in many parts of the tropics and sub-tropics. A number of diseases result in serious losses to this economically important forest resource. Eucalyptus rust, caused by Puccinia psidii, is one such example. The economic losses due to this disease are the result of infections of seedlings, young trees, and coppice. P. psidii occurs predominately in Central and South America, but reports of a similar rust are known from other areas. Eucalyptus rust is a remarkable disease in that the pathogen is not known on eucalypts in their centers of origin. It has apparently originated on native Myrtaceae in South America and is highly infective on some Eucalyptus spp. planted there. P. psidii causes one of the most serious forestry diseases in Brazil and is considered to be the most serious threat to eucalypt plantations worldwide. Advances in eucalyptus rust research are reviewed here, with a focus on topics such as distribution, host range, pathogen specialization, symptomatology, etiology, epidemiology, and control.
\end{abstract}

The Myrtaceae family includes a number of economically important tree crops, notably Eucalyptus spp., Psidium guajava, Pimento officialis, and Syzygium aromaticum. The greater portion of this family occurs in the Australasian and Southeast Asian regions, and in Central and South America, with four genera native to southern Africa $(35,49,55)$. Of the economically important tree crops, Eucalyptus spp. are most significant and make up over eight million hectares of forest plantations in the tropics and sub-tropics (52). Diseases are thus considered to be a major threat to this forestry resource (57).

During the course of the past century, a number of genera and species of rust fungi have been reported to infect members of Myrtaceae. The majority of these species belong to the genus Puccinia Pers., while others are found in the genera Aecidium Pers., Caeoma Link, Melampsora Castagne, Uredo Pers., and Uromyces (Link) Unger (51). Further

\section{Corresponding author: T. A. Coutinho \\ E-mail: Coutinho@scientia.up.ac.za}

Accepted for publication 3 March 1998.

Publication no. D-1998-0423-01S

(C) 1998 The American Phytopathological Society taxonomic investigations have, however, led researchers to synonymize many of these genera $(29,54)$.

Many of the rust fungi naturally infecting Myrtaceae occur on a wide variety of hosts. Puccinia psidii Winter is the only rust confirmed to be capable of infecting Eucalyptus spp. This fungus has also been reported to infect 10 other genera of Myrtaceae. The pathogen was first described by Winter (58) in 1884 on Psidium pomiferum in Brazil. In 1912, it was observed on Eucalyptus citriodora (26) but was not formally described from this host until 1944 (29). The first serious outbreak of $P$. psidii on a Eucalyptus sp. occurred in 1973 in the Brazilian province of Espirito Santo, where large-scale losses were experienced in nurseries and young plantations of $E$. grandis established from South African seed sources $(20,21)$.

Puccinia psidii is currently a serious threat to eucalyptus plantations in many parts of the world, and particularly in Australia, where eucalypts are native. Considering the serious nature of eucalyptus rust and its international importance, this review is provided for a wider literary audience. Ferreira $(21,23)$ published reviews on the history, biology, and control of eucalyptus rust in Portuguese. Here we discuss advances in research on topics relating to its distribution, host range, pathogen spe- cialization, symptomatology, etiology, epidemiology, and disease control.

Distribution. $P$. psidii has been reported from South America (Argentina, Brazil, Colombia, Ecuador, Paraguay, Uruguay, and Venezuela), Central America, the Caribbean (Cuba, Dominican Republic, Jamaica, Puerto Rico, and Trinidad) (32), and South Florida (34). A rust, suggested to be $P$. psidii, has recently also been reported from Taiwan on E. camaldulensis (56). In this case, only a uredinial state was reported and it is impossible to confirm whether the fungus was the same as $P$. psidii. Despite considerable effort, the fungus has not been seen again (W. Wang, Taiwan Forestry Research Institute, per-

Table 1. List of reported hosts of Puccinia psidii; all belong to the family Myrtaceae

\begin{tabular}{|c|c|}
\hline Host & Reference \\
\hline Callistemon speciosus (Sims) DC & 32 \\
\hline Eucalyptus camaldulensis Dehnhardt & 19 \\
\hline E. citriodora Hook. & 26 \\
\hline E. cloeziana F. Muell. & 19 \\
\hline E. grandis Hill ex Maiden & 20 \\
\hline E. maculata Hooker & 19 \\
\hline E. microcorys $\mathrm{F}$. Mueller & 19 \\
\hline E. paniculata $\mathrm{Sm}$. & 19 \\
\hline E. pellita $\mathrm{F}$. Mueller & 19 \\
\hline E. phaeotricha Blakely et Mckie & 19 \\
\hline E. pirocarpa L. Johnson, D. Blaxell. & 19 \\
\hline E. punctata De Condolle & 19 \\
\hline E. saligna Smith & 21 \\
\hline E. tereticornis $\mathrm{Sm}$. & 19 \\
\hline E. urophylla S.T. Blake & 19 \\
\hline Eugenia brasilenssis Lam. & 53 \\
\hline E. jambolana Lam. & 53 \\
\hline E. malaccensis L. & 32 \\
\hline Eugenia sp. & 54 \\
\hline E. uniflora L. & 53 \\
\hline E. uvalha Camb. & 32 \\
\hline Marlierea edulis Niedz & 54 \\
\hline Melaleuca leucodendron (L.) L. & 54 \\
\hline Myrcia jaboticaba Berg & 54 \\
\hline Myrcia spp. & 32 \\
\hline Myrciaria sp. & 54 \\
\hline Pimenta acris Kostel & 32 \\
\hline P. dioica (L.) Merr. & 34 \\
\hline P. officialis $\mathrm{L}$. & 3,33 \\
\hline Psidium araça Raddi & 54 \\
\hline$P$. guajava $\mathrm{L}$. & 58 \\
\hline P. pomiferum $\mathrm{L}$. & 58 \\
\hline Syzygium jambos (L.) Alston & 32 \\
\hline
\end{tabular}


sonal communication). Another rust infecting Eucalyptus spp. has been reported from India, where it was identified as a species of Melampsora (53). Type material of the latter fungus has, however, failed to reveal whether this identification was correct (I. Gibson, personal communication). Recently, Knipscheer and Crous (30) reported a rust on E. nitens in South Africa. This fungus was not successfully identified to genus, due to the absence of teliospores, and it has subsequently disappeared from forest plantations.

Host range and pathogen specialization. P. psidii is capable of infecting many species in the Myrtaceae (Table 1; Fig. 1A and B). This fungus was originally described from infected $P$. pomiferum leaves (58) and, in 1904, Sydow and Sydow (51) listed only Psidium spp. as hosts. Arthur $(4,5)$ and Stevenson (50) listed only $P$. guajava and $S$. jambos as hosts, but Joffily (29), Viégas (54), and Laundon and Waterston (32) listed several other genera as hosts of $P$. psidii. Joffily (29) and Viégas (54) considered several of the rusts described on various genera of Myrtaceae as not being distinct from $P$. psidii. Their conclusions were not based on detailed taxonomic studies, and until such a study is complete, the host range of $P$. psidii will remain enigmatic.

Cross-inoculations among hosts indicate that there is considerable physiological variability within $P$. psidii $(7,8,12,14,20$, 23,33). Ferreira (23) suggested that the host range has expanded within the Myrtaceae family. He speculated that the wild ancestor of $P$. psidii was able to infect a number of species, such as $S$. jambos, Eucalyptus spp., Myrcia jaboticaba, Callistemom speciosus, and wild and commercial varieties of $P$. guajava. Reciprocal cross-inoculations among these hosts were preformed (23), and it was found that only
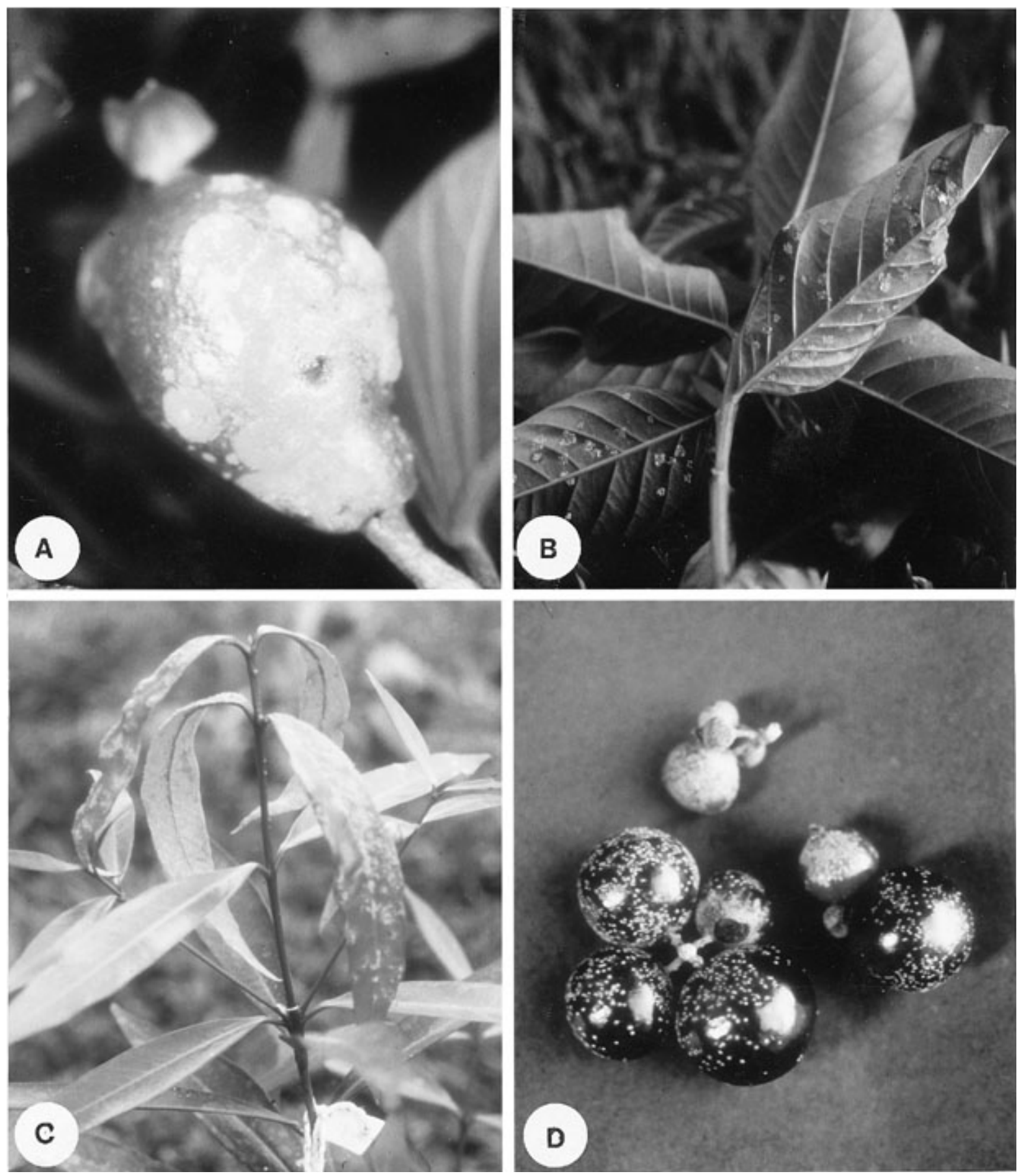

Fig. 1. Pustules of Puccinia psidii on different hosts. (A) Psidium guajava fruit. (B) P. guajava leaves. (C) Syzygium jambos leaves. (D) Myrcia jaboticaba fruit. 
the urediniospores collected from the wild and commercial $P$. guajava were incapable of infecting the other species. Castro et al. $(12,15)$ reported that spores collected from $P$. guajava were able to infect various clones of E. grandis. Coelho (7), in a cross-inoculation study with single pustule isolates from Eucalyptus spp., P. guajava, and $S$. jambos, reported that there are three physiological groups of $P$. psidii. Group 1 infects Eucalyptus spp. and $S$. jambos, Group 2 infects Eucalyptus spp. and $P$. guajava, and Group 3 is able to infect $P$. guajava only. The apparent contradiction in the results obtained by the researchers who have conducted cross-inoculation studies may be due to race differences within $P$. psidii. Races or formae speciales of this pathogen have yet to be described, but as is the case with other rust fungi, such as coffee rust (Hemileia vastatrix Berk. \& Br.; 6), they seem likely to exist.

Symptomatology. Eucalyptus spp. are most susceptible to infection by $P$. psidii
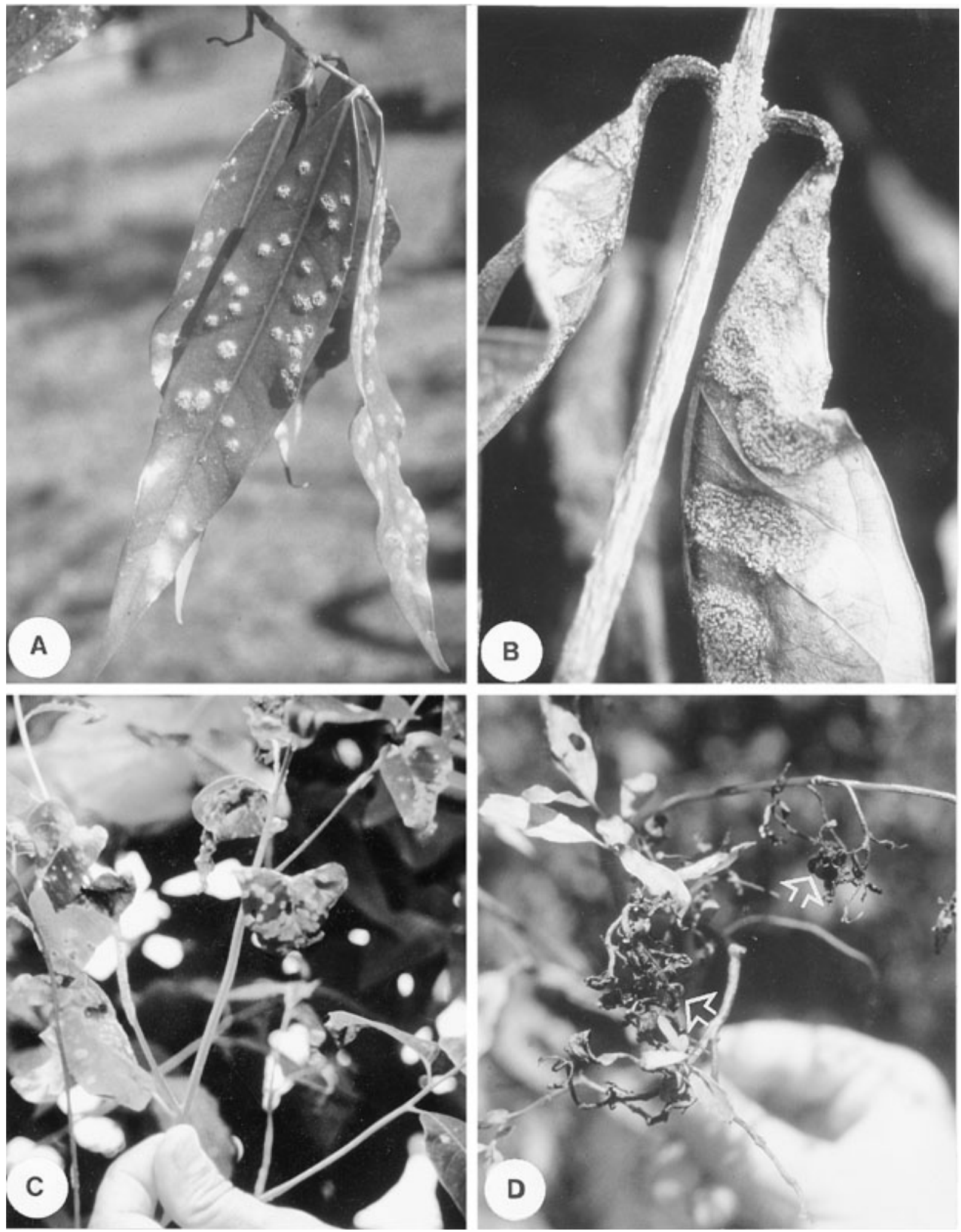

Fig. 2. Symptoms of eucalyptus rust on Syzygium jambos and Eucalyptus spp. (A) The characteristic egg-yolk yellow pustules on $S$. jambos leaves. (B) Stem and leaves of $S$. jambos showing the coalescence of uredinia. (C) Infection of the stem and leaves of Eucalyptus sp. showing the coalescence of pustules, necrosis, and hypertrophy. (D) Tip die-back (arrows) of $E$. grandis following infection. 
when they are less than 2 years old $(3,20,21)$. The first symptoms of eucalyptus rust become visible 2 to 4 days after the host has been inoculated with urediniospores (23). According to Ferreira (21) and Alfenas et al. (2), the first evidence of attack by this fungus is the appearance of pale yellow specks on the leaf buds. Within 10 to 12 days after inoculation with urediniospores, the specks deepen in color to a characteristic egg-yolk yellow and uredinia become visible under a dissection microscope (Fig. 2A). Thereafter, the infected areas increase in size in a circular manner due to the radial growth of the fungus. Infected areas often coalesce with age (Fig. 2B). Secondary infections occur within a few days and are confined to new plant tissues, such as primordial leaves, their petioles, and branch tips. In severe cases, the main and secondary juvenile branches of young plants are attacked (Fig. 2C). When the tissue is susceptible, the infected parts of the tree shrivel and die (Fig. 2D).

When leaves that have reached $50 \%$ of their full growth are infected by $P$. psidii, less intense sporulation is displayed and is usually restricted to the lower leaf surfaces (23). Pustules in this case are generally confined to areas between the veins, and the leaves are often deformed. Sporulation of $P$. psidii on infected parts of seedlings ceases after 2 weeks. Tips of branches and the main stem then display hypertrophy and diagnosis becomes difficult. Eucalyp- tus rust rarely kills its host, except when it is found on coppice growth of highly susceptible Eucalyptus spp. Plants recover by producing new growth that may become infected if the conditions are favorable. If the trees are continuously re-infected they become stunted (45).

Life cycle. The life cycle of $P$. psidii remained unknown until the early 1980s. It has since been discovered that this fungus has a macrocyclic life cycle (Fig. 3). The following states occur: aecia (state 1), uredinia (state 2), telia (state 3), and basidia (state $4 ; 23,33$ ). Spermatia (state 0 ) have not as yet been found (23), but due to the reported occurrence of aecia (25) this stage must exist. This fungus is also considered to be autoecious (25).

The only study conducted on the morphology of the different stages in the life cycle of $P$. psidii is one described by Ferreira (23). Teliospores are dark brown in color and are pedicellate, bicellular, and club-shaped, with a flattened papilla on the wall distal to the pedicel cell ( 15 to 28 by 30 to $60 \mu \mathrm{m}$; Fig. 4A). Pustules may consist of a mixture of teliospores and urediniospores, but these spore types may also be produced in telia (Fig. 4B) and uredinia (Fig. 4C) only. Either one or both cells of the teliospore germinate to form basidia under humid conditions. A very low percentage $(8 \%)$ of teliospores is reported to germinate (9). Basidia are 40 to $70 \mu \mathrm{m}$ in length and only $0.1 \%$ produce basidio- spores, which are borne on sterigmata (23). Aeciospores have the same morphology as urediniospores. The shape of both spore types is variable; they may be pyriform to spherical or oval with angular outer walls (10 to 20 by 15 to $25 \mu \mathrm{m}$; Fig. 4D). Aeciospores have been found only on $S$. jambos (25).

Teliospores and basidiospores are seldom found on naturally infected eucalyptus trees (21). However, Ruiz (38) reported that teliospores occur under natural conditions in Brazil on E. cloeziana during the warmer months of the year (December to March). They are, however, frequently found on $S$. jambos and occasionally on $M$. jabaticaba under natural conditions. Many teliospores are produced on artificially inoculated Eucalyptus spp. and S. jambos (38). Basidiospores have been shown to infect only $S$. jambos, and then only at temperatures greater than $25^{\circ} \mathrm{C}(25)$. Aeciospore formation usually occurs 10 to 18 days following infection (25).

Infection process. In the presence of free water, in darkness, and at temperatures between 15 and $25^{\circ} \mathrm{C}$, urediniospores germinate on the host surface $(11,16,23$, 37,40,44,46). In Brazil, these ideal environmental conditions are experienced from May to August, and the highest levels of rust were recorded during this period $(19,43,45)$. However, favorable periods for infection may vary from year to year and according to the geographic region. Light

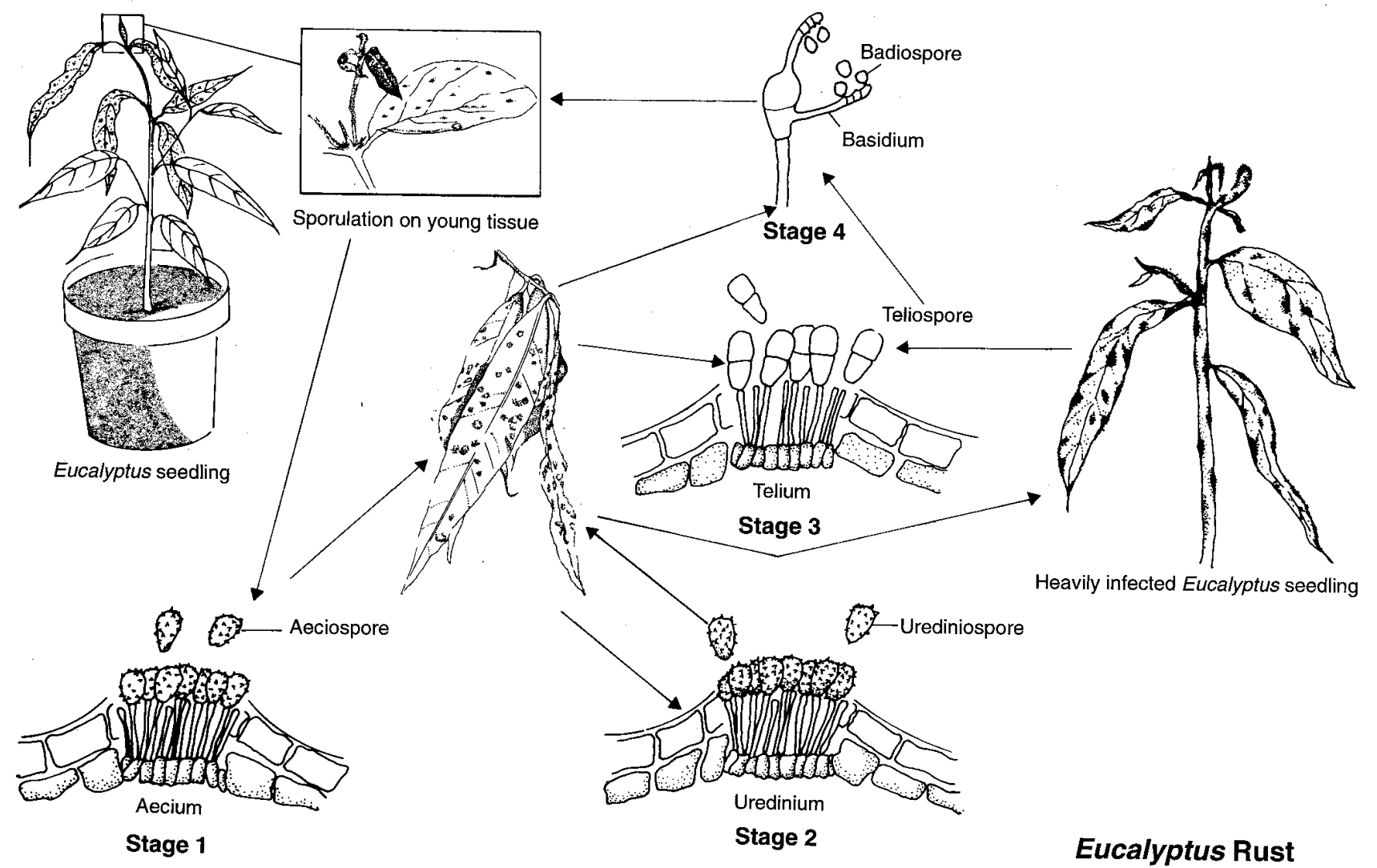

Fig. 3. Diagrammatic representation of the life cycle of Puccinia psidii. 
has been found to inhibit germination $(46,47)$ and at least $8 \mathrm{~h}$ of darkness are required for successful infection (36). In an infection study conducted by Hunt (28) on $S$. jambos inoculated with $P$. psidii urediniospores, the following was observed: a single, unbranched germ tube was formed, a thin-walled, globose or ellipsoidal appressorium developed from the tip of the germ tube, and an infection peg penetrated the host directly (Fig. 4E). Penetration usually took place between two epidermal cells or, less commonly, in the corners between three epidermal cells. This penetration procedure has been observed on hosts other than $S$. jambos, including Eucalyptus spp. (23). Urediniospore germ tubes of only a few rust fungi are capable of direct penetration (28). $H$. vastatrix, for example, relies on stomata for entry into the host (27).

Studies on the host-pathogen interaction between $P$. psidii and Eucalyptus spp. con- ducted in Brazil have shown that urediniospores germinate on both young and mature leaves of susceptible and resistant genotypes (A. Xavier, A. C. Alfenas, and K. Matsuoka, unpublished data). On mature leaves of Eucalyptus spp., germination is retarded and the number of appressoria formed is much lower than on juvenile leaves. Direct penetration occurs on young leaves of both resistant and susceptible genotypes within $24 \mathrm{~h}$ after inoculation. In resistant genotypes, the haustoria formed within the host cells and the surrounding cells underwent a hypersensitive reaction and collapsed. Following penetration on the susceptible genotype, the fungus ramifies intercellularly through the host tissue. A temperature of $15^{\circ} \mathrm{C}$ has been found to promote mycelial growth within the host (23). Haustorium mother cells are formed from the infection hyphae (23); from these cells, lobe-shaped haustoria then formed within the host cells. Germ tubes of basidiospores and aeciospores are also reported to penetrate the host directly (25).

In incompatible reactions, either as a result of infection of a non-host or a resistant host, punctate, atypical pustules are formed on the broadest part of the leaf (24). These pustules are smaller in size, and sporulation takes place only in the center of the infected area. Fewer "normal" pustules are formed on the incompatible tissue. A hypersensitive reaction $(7,23)$, which results in the death of a few cells at the site of penetration, has also been observed.

Epidemiology. The fungus has a latent period, from the beginning of incubation to the time at which $50 \%$ of the first uredinia appeared, of 5 to 7 days (1). This is considerably shorter than, for example, the latent period of $H$. Vastatrix, which ranges from 30 to 60 days (10). Castro et al. (13) showed that most urediniospores of $P$.
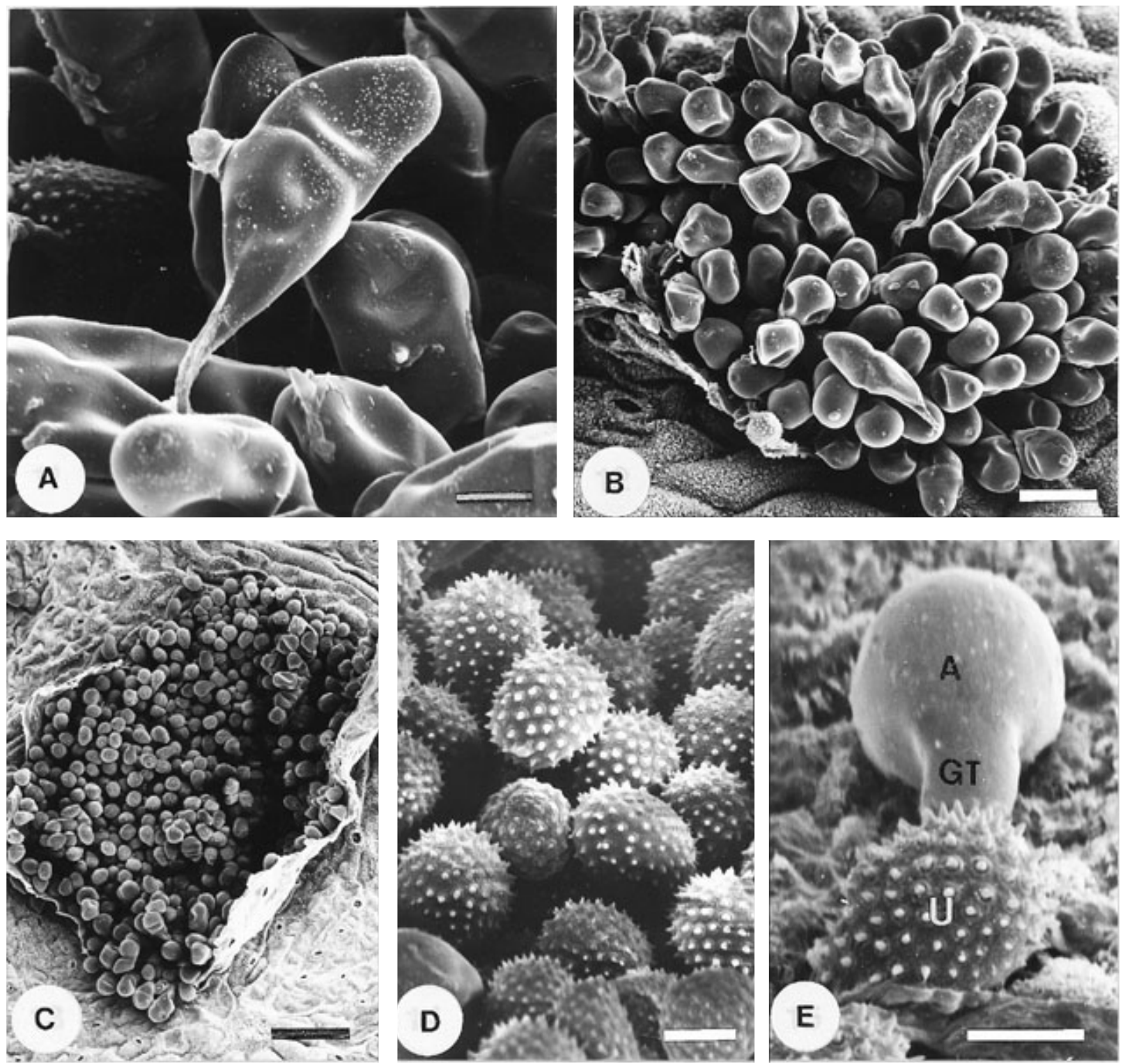

Fig. 4. Scanning electron micrographs of the spore types and infection process of Puccinia psidii on Eucalyptus sp. leaves. (A) Two-celled teliospores (bar $10 \mu \mathrm{m}$ ). (B) Telium (bar $20 \mu \mathrm{m}$ ). (C) Uredinium (bar $100 \mu \mathrm{m}$ ). (D) Single-celled urediniospores (bar $10 \mu \mathrm{m}$ ). (E) Urediniospore (U), germ tube (GT), and appressorium (A) on the leaf surface (bar $20 \mu \mathrm{m})$. 
psidii are produced within the first 10 days after infection, although the number of urediniospores did depend on the host.

Temperatures of 15 and $30^{\circ} \mathrm{C}$ inhibit uredinial sporulation (42). The ideal temperature for the generation of urediniospores of $P$. psidii has been found to be $20^{\circ} \mathrm{C}$ (20). Infected plants maintained at $25^{\circ} \mathrm{C}$ are more likely to produce telia than uredinia (42). Light, following the incubation period, enhances the production of both telio- and urediniospores $(42,47)$.

After the first uredinial pustules appear, secondary infections arise on host tissue. The urediniospores from these pustules spread to susceptible tissue by rain, insects, and wind (21). It has been suggested that primary infections result from inoculum originating from hosts other than eucalypts, or from basidiospore/aeciospore infection (21).

\section{Control}

Three methods are recommended for disease control: disease avoidance, planting resistant genotypes, and fungicide applications. The latter strategy, however, is practical only in nursery situations and on coppice (2).

Disease avoidance. Eucalypts are highly susceptible to $P$. psidii at physiological growth stage A (0 to 2 years old). They are less frequently attacked at stage B (2 to 4 years old) and rarely at stage $C$ (4 years to harvesting; 22). Older plantations, therefore, have very low levels of rust. Environmental conditions also may not be ideal for infection to occur on the actively growing tissue in taller trees. Coppice growth also has been found to be extremely susceptible to $P$. psidii (21). Therefore, it is recommended that trees are not felled when environmental conditions are ideal for infection to occur (46). Also, cuttings should be harvested only from clonal hedges under conditions that do not favor infection by $P$. psidii (46). Alternatively, fungicides can be used to protect the young shoots in this situation $(1,2)$.

Use of resistant genotypes. There is considerable genetic variability within and between Eucalyptus spp., and infection studies have shown clear differences in their susceptibility to $P$. psidii (11,1719,23). From most- to least-susceptible, they include: E. cloeziana, E. phaeotricha, E. grandis, E. citriodora, E. camaldulensis, E. tereticornis, E. urophylla, E. maculata, E. paniculata, E. punctata, E. pirocarpa, E. microcorys, E. pellita, and E. saligna. It has been recommended that the most susceptible species not be planted in countries where the fungus is known to occur. In field trials after a severe attack by P. psidii, individual trees of some Eucalyptus spp. have been selected that appear resistant (23). Potentially, these can be vegetatively propagated for clonal plantings.

Many Eucalyptus spp. from specific provenances have been tested for their susceptibility to $P$. psidii $(11,17,23)$. Parameters used to quantify resistance of Eucalyptus spp. to $P$. psidii include the ratio of diseased to healthy leaves and twigs, and the number and size of pustules $(12,17)$ and uredinia $(7,46,47)$. The latent and generation periods also have been used (37). Trees in plantations have been visually rated using a 0 to 3 scale, where $0=$ healthy, 1 = resistant, 2 = moderately susceptible, and $3=$ susceptible (21).

Wide-scale plantings of $E$. grandis seed from South Africa led to severe outbreaks of eucalyptus rust in Brazil between 1973 and 1978, and it has subsequently become one of the most serious diseases in that country $(20,21,31)$. The susceptible seedlots were reported to be provenances of $E$. grandis (18). However, the E. grandis sent to Brazil from South Africa in the 1970s (N. Denison, Mondi Forests, personal communication) were commercial seedlots and not provenances, as has been reported in the literature.

Fungicides. Fungicides can be successfully employed for disease control in eucalypt nurseries and on coppice $(2,3,39,41$, 44,48). Among the protectant fungicides tested, mancozeb was the most effective against the pathogen when applied 10 days prior to infection. The systemic fungicides triademenol, triforine, oxycarboxin, and diniconazole were found to be translocated in young tissue and were reported to prevent infection successfully $(2,17,44)$.

\section{International Importance}

$P$. psidii is an unusual rust in that it has an extremely wide host range amongst genera and species of Myrtaceae. Its occurrence on Eucalyptus spp. appears to be one of the unexpected and unfortunate consequences of exposing the rust to this host in a non-native situation. The occurrence of $P$. psidii on Callistemon speciosus, another Australian myrtaceous plant, in South America, is an example of the same phenomenon. At this stage it would appear that a race or races of the rust are well established on Eucalyptus spp. The potential for these fungi to result in epidemic disease situations in the areas of origin of Eucalyptus spp., and perhaps other myrtaceous genera, seems real, and could be a serious threat to global biodiversity. Such a situation would be equivalent to other introduced epidemic tree diseases, such as Dutch elm disease (caused by Ophiostoma ulmi (Buisman) Nannf. and O. novo-ulmi Brasier), chestnut blight (caused by Cryphonectria parasitica Murrill (Barr), pine wilt (caused by Bursaphelenchus xylophilus Steiner \& Buhrer), and white pine blister rust (caused by Cronartium ribicola J.C. Fisch).

The three occurrences of rust on Eucalyptus spp. outside South and Central America are enigmatic. In all three cases (South Africa, Taiwan, and India), the rusts have been typified only by the uredinial states, and definitive species identifications have not been made. Only in the case of Taiwan was the rust identified as $P$. psidii (56). Wingfield (unpublished data) also conducted morphological comparisons, including scanning electron microscopy, of the rusts from Taiwan and Brazil and could find no differences between them. Indeed, if the rust in Taiwan is the same as that occurring in Brazil, it is possible that it has been introduced from South or Central America. Given the proximity of Taiwan to Australia, the threat of introduction to eucalypts in their native range would appear to be even more severe.

The wide host range of $P$. psidii makes it a tree pathogen of considerable global importance. Despite this fact, it has not received particularly great attention other than in Brazil, where it causes serious damage to a number of commercial crops. Many, if not most, forest pathologists in the international arena are unaware of this important pathogen, or at least are oblivious to its importance. It is hoped that this review will highlight its significance and possibly even lead to an international effort to evaluate the potential threat associated with it.

\section{Conclusions}

$P$. psidii is considered to be one of the most serious threats to Eucalyptus spp. in the world today. Strict quarantine measures are necessary to prevent the entry of this fungus into countries where it does not occur, particularly in Australia, where Eucalyptus spp. are native and where epidemic losses could potentially be experienced. Foresters, pathologists, and mycologists involved in quarantine measures should, therefore, be aware of the characteristics of this rust fungus and symptoms associated with infection.

A detailed taxonomic study is needed to determine the host range and geographical distribution of $P$. psidii. It still is not certain whether more than one species of Puccinia is capable of infecting members of the Myrtaceae. Comparisons at the molecular level would be particularly useful in this regard.

In order to successfully implement a breeding program, the races of $P$. psidii must be identified. In this respect, comprehensive studies should be undertaken to determine which races are present, the host range of these races, and which race or races are predominant in different regions.

Uncertainty exists on aspects of the life cycle and infection process of $P$. psidii. Modern technology, including electron microscopy and molecular genetic comparisons, will provide researchers with an understanding of the etiology of the disease as well as the behavior of the fungus on incompatible tissue.

\section{ACKNOWLEDGMENTS}

We thank the South African forest industry and the Foundation for Research Development (FRD) for financial assistance; and the Financiadora de Projetos (Finep) and the Conselho Nacional de 
Desenvonlvimento Cientifico e Tecnolõgico (CNPq) for the financial support of research projects on eucalyptus rust in Brazil.

\section{LITERATURE CITED}

1. Alfenas, A. C., Demuner, N. L., and Barbosa, M.M. 1989. A ferrugem e as opções de controle. Correio Agric. 1:18-20.

2. Alfenas, A. C., Maffia, L. A., and Sartorio, R. C. 1993. Eficiência de triadimenol, oxicarboxim e diniconazole para o controle da ferrugem, Puccinia psidii, em brotaçóes de Eucalyptus cloeziana, em condiçóes de campo. Rev. Árvore 17:247-263.

3. Anon., 1963, 1964. Study of pimento rust. (Abstr. 2204) Rev. Appl. Mycol. 45:393.

4. Arthur, J. C. 1915. Uredinales of Poerto Rico based on collections by F. L. Stevens. Mycologia 7:227-255

5. Arthur, J. C. 1922. Uredinales. North Am. Flora 7:481-540.

6. Bettencourt, A. J., and Rodrigues, C. J. Jr. 1988. Principles and practice of coffee breeding for resistance to rust and other diseases. Pages 199-235 in: Coffee Agronomy, Vol. 4. R. J. Clarke and R. Macrae, eds. Elsevier, London.

7. Coelho, L. 1988. Variabilidade físiologica de Puccinia psidii Winter-ferrugem do eucalipto. Tese (M.S.), Universidade Federal de Viçosa, Viçosa.

8. Coutinho, L. N., and Figueiredo, M. B. 1984. Estudos sobre especializações fisiológicas em Puccinia psidii Winter. VII. (Abstr. 33) Congr. Paulista Fitopatol. UNESP, Botucatu, SP.

9. Coutinho, L. N., and Figueiredo, M. B. 1984. Influência da temperatura na geminação de teliosporos e liberação de basidiosporos de Puccinia psidii Winter. VII. (Abstr. 6) Congr. Paulista Fitopatol. UNESP, Botucatu, SP.

10. Coutinho, T. A. 1991. Studies on the expression of resistance of Coffea selections to Hemileia vastatrix. Ph.D. thesis, University of Natal, South Africa.

11. De Carvalho, A. O. 1992. Progresso da ferrugem (Puccinia psidii Winter) do eucalipto no sudeste da Bahia e resistência de espécies de Eucalyptus á doença. Tese (M.S.), Universidade Federal de Viçosa, Viçosa

12. De Castro, H. 1983. Padronização de metodologia de inoculação e availiação de resistência de Eucalyptus spp. á ferrugem causada por Puccinia psidii Winter. ESALQ, Piracicaba, SP.

13. De Castro, H. A., Filho, A. B., and Krügner, T. L. 1984. Padrão de produção de uredosporos em mudas de Eucalyptus spp. inoculadas artificialmente com Puccinia psidii. Summa Phytopathol. 10:155-170.

14. De Castro, H. A., Krügner, T. L., Ideriha, C. H. F., Cappello, M. S. C., and Marchi, A. B. 1983. Inoculação cruzada de Eucalyptus, goiaba (Psidium guajava) e jambeiro (Syzygium jambos) com Puccinia psidii. Fitopatol. Bras. 8:491-497.

15. De Castro, H. A., Krügner, T. L., and Filho, A. B. 1985. Especialização fisiológica no sistema Eucalyptus grandis W. Hill ex Maiden-Puccinia psidii Winter. Cienc. Prat. Lavras. 9:80-92.

16. De Castro, H. A., and Krügner, T. L. 1984. Padronização de metodologia de inoculacao de Puccinia psidii Winter em Eucalyptus para avaliação de resisténcia do hospedeiro. VII. (Abstr. 67) Congr. Paulista Fitopatol. UNESP, Botucatu, SP.

17. Demuner, N. L., and Alfenas, A. C. 1989 Fungicidas sistêmicos para o controle da ferrugem do eucalipto causada por Puccinia psidii. (Abstr. 263) Fitopatol. Bras. 14:156.

18. Dianese, J. C., Moraes, T. S., and Haridasan, M. 1986. Screening Eucalyptus species for rust resistance in Bahia, Brazil. Trop. Pest Manage. 32:292-295.

19. Dianese, J. C., Moraes, T. S., and Silva, A. R. 1984. Response of Eucalyptus species to field infection by Puccinia psidii. Plant Dis. 68:314-316.

20. Ferreira, F. A. 1981. Ferrugem do eucaliptoocorrência, temperatura para geminação de uredosporos, produção de teliosporos, hospedeiro alternativo e resistência. Fitopatol. Bras. 6:603-604.

21. Ferreira, F. A. 1983. Ferrugem do eucalipto. Rev. Árvore 7:91-109.

22. Ferreira, F. A. 1986. Enfermidades do eucalipto. Inf. Agropecu. 12:59-70.

23. Ferreira, F. A. 1989. Ferrugem do eucalipto. Pages 129-152 in: Patologia Florestal-Principais Doenças Florestals no Brasil. Sociedade de Investigaçoes Florestais/Universidade Federal de Viçosa, Viçosa, MG.

24. Ferreira, F. A., and Silva, A. R. 1982. Comportamento de procedências de Eucalyptus grandis e de E. saligna à ferrugem (Puccinia psidii). Fitopatol. Bras. 7:23-27.

25. Fiqueiredo, M. B., Coutinho, L. N., and Hennen, J. F. 1984. Estudos para determinção do cicio vital de Puccinia psidii Winter. VII. (Abstr. 32) Congr. Paulista Fitopatol. UNESP, Botucatu, SP

26. Gonçalves, S. 1929. Lista preliminar das doenças das plantas do Estado do Espírito Santo. Rio de Janeiro, Ministério da Agricultura. pp. 1-12.

27. Gospalkrishnan, K. S. 1951. Notes on the morphology of the genus Hemileia. Mycologia 43:271-283.

28. Hunt, P. 1968. Cuticular penetration by germinating uredospores. Trans. Br. Mycol. Soc. 51:103-112.

29. Joffily, J. 1944. Ferrugem do eucalipto. Bragantia 4:475-487

30. Knipscheer, N., and Crous, P. 1990. First record of a rust disease on Eucalyptus. For. News 2/90:22-23.

31. Krügner, T. L. 1980. Doenças do eucalipto. Pages 275-296 in: Manual de Fitopatologia, F. Galli, coordinator. 2nd ed. São Paulo, Agronômica Ceres. V. 2.

32. Laundon, G. F., and Waterston, J. M. 1965. Puccinia psidii. CMI Descriptions of Pathogenic Fungi and Bacteria No. 56. Commonw. Mycol. Inst., Kew, Eng.

33. MacLachlan, J. D. 1938. A rust of the pimento tree in Jamaica. Phytopathology 28:157-170.

34. Marlatt, R. B., and Kimbrough, J. W. 1979 Puccinia psidii on Pimento dioica in South Florida. Plant Dis. 63:510-512.

35. Palgrave, K. C. 1983. Trees of Southern Africa. Struik Publishers, Cape Town, South Africa.

36. Piza, S. M. T., and Ribeiro, I. J. A. 1988. Influência da luz e temperatura a germinação de uredosporos de Puccinia psidii Winter. Bragantia 47:75-78.

37. Piza, S. M. T., and Ribeiro, I. J. A. 1989. Influência da temperatura, tipo de ãgua e período de incubação sobre a germinação de uredosporos de Puccinia psidii. Summa Phytopathol. 15:222-226.

38. Ruiz, R. A. R. 1988. Epidemiologia e controle químico da ferrugem (Puccinia psidii Winter) do eucalipto. Tese (M.S.) Universidade Federal de Viçosa, Viçosa, MG

39. Ruiz, R. A. R., and Alfenas, A. C. 1989. Absorção e translocação de fungicidas sistêmicos em Eucalyptus grandis para o controle da ferrugem do eucalipto, causada por Puccinia psidii. Fitopatol. Bras. 14:47-50.

40. Ruiz, R. A. R., Alfenas, A. C., and Barbosa, M. M. 1987. Influênia da temperatura e umidade relativa sobre o desenvolvimento da ferrugem do eucalipto causada por Puccinia psidii em condições de campo. (Abstr. 104) Fitopatol. Bras. 12:137.

41. Ruiz, R. A. R., Alfenas, A. C., and Demuner, N. L. 1991. The efficiency of fungicides for the control of rust (Puccinia psidii) on guava (Psidium guajava). Summa Phytopathol. 17:147-153.

42. Ruiz, R. A. R., Alfenas, A. C., and Ferreira, F A. 1989. Influência da temperatura luz e origem do inoculo sobre a produção de uredosporos e teliosporos de Puccinia psidii. Fitopatol. Bras. 14:70-73.

43. Ruiz, R. A. R., Alfenas, A. C., Ferreira, F. A., and Ribeiro DoVale, F. X. R. 1989. Influência da temperatura, do tempo de molhamento foliar, fotoperiodo e da intensidade de luz sobre a infecção de Puccinia psidii em eucalipto. Fitopatol. Bras. 14:55-61.

44. Ruiz, R. A. R., Alfenas, A. C., Ferreira, F. A. and Zambolim, L. 1987. Fungicidas protetores e sistêmicos para o controle da ferrugem do eucalipto, causada por Puccinia psidii. Rev. Árvore 11:56-65.

45. Ruiz, R. A. R, Alfenas, A. C., Maffia, L. A. and Barbosa, M. M. 1989. Progresso da ferrugem do eucalipto, causada por Puccinia psidii, em condições de campo. Fitopatol. Bras. 14:73-81.

46. Ruiz, R. A. R., Alfenas, A. C., and Ribeiro Do Vale, F. X. R. 1987. Influência da luz e do binômio temperatura-tempo de água líquida para infecção de Puccinia psidii em Eucalyptus grandis. (Abstr. 103) Fitopatol. Bras. 12:137.

47. Ruiz, R. A. R., Alfenas, A. C., and Ribeiro Do Vale, F. X. R. 1987. Influência da temperatura, luz e do hospedeiro sobre a produção de teliosporos e infecção de Puccinia psidii em Eucalyptus grandis. (Abstr. 102) Fitopatol. Bras. 12:158

48. Ruiz, R. A. R., Alfenas, A. C., and Zambolim, L. 1987. Efeito protetor e curativo de fungicidas para controle de Puccinia psidii em Eucalyptus grandis e Psidium guajava. (Abstr. 057) Fitopatol. Bras. 12:129.

49. Shivas, R. G., and Walker, J. 1994. Puccinia cygnorum sp. nov. on Kunzea ericifolia (Myrtaceae) in Australia. Mycol. Res. 98:2224.

50. Stevenson, J. A. 1975. Fungi of Puerto Rico and the American Virgin islands. Contrib. Reed Herb. No. 23, iv + 743 pp

51. Sydow, P., and Sydow, H. 1904-1924. Monographia Uredinearum seu specierum omnium ad hunc usque diem cognitarum descriptio et adumbratio systematica. Vol. (1904), Vol. 3 (1915), and Vol. 4 (1924) Borntraeger Bros., Leipzig, Germany.

52. Turnbull, J. W. 1991. Future use of Eucalyptus: opportunities and problems. Pages 2-29 in: IUFRO Symposium on Intensive forestry: the role of eucalypts. Vol. 1. Durban, South Africa.

53. Upadhyay, D. N., and Bordoloi, D. N. 1974 New records of diseases on cultivated essential oil bearing plants from North-East India. Indian Phytopathol. 28:532-534.

54. Viégas, A. P. 1961. Indice de Fungos da América do Sul. Instituto Agronòmico, Campinas, Brazil.

55. Walker, J. 1983. Pacific mycogeography: deficiencies and irregularities in the distribution of plant parasitic fungi. Aust. J. Bot. Suppl. Ser. 10:89-136.

56. Wang, W. 1992. Survey of Eucalyptus Dis eases in Taiwan. Bull. Taiwan For. Res. Inst. New Ser. 7:179-194.

57. Wingfield, M. J. 1990. Current status and future prospects of forest pathology in South Africa. S. Afr. J. Sci. 86:60-62.

58. Winter, G. 1884. Repertorium. Rabenhorstii fungi europaei et extraeuraopaei. Cent. XXXI et XXXII. Hedwigia 23:164-172. 